\title{
血液透析施行中の血圧変動と二次微分脈波の波形変化
}

\author{
鈴木 尚 紀 $^{1}$ 水野(松本)由子 ${ }^{2}$ 川崎 由 記 $^{1}$ 橘 銀 平 ${ }^{1}$ \\ 押 $千$ 穂 $^{1}$ 蓮池 由起子 ${ }^{3}$ 中 西 健 $^{3}$ \\ ${ }^{1}$ 兵庫医科大学病院臨床工学室 ${ }^{2}$ 兵庫県立大学大学院応用情報科学研究科 \\ 3 兵庫医科大学内科学腎・透析科
}

キーワード：透析低血圧, 二次微分脈波, 血液透析, 循環血液量, 動脈硬化

〈要旨〉

本検討は, HD 施行前の SDPTG 波形パターンの違いによる患者因子の特徴と, HD 施行中に反復測定した SDPTG 波形と血圧との関連性について検討した. HD 患者 81 名を対象とした. 二次微分脈波の波形より正常型（Ｉ型）と 異常型（I型）に，さらに川型を，心拍出量と関連するとされる $\mathrm{c}$ 波の有無より川-a 型と川-b 型に分けた. HD 施 行前の SDPTG が II 型波形を示す患者では， I 型波形患者に比較して血管石灰化や PAD の合併率が高かった．HD 施行中の血圧は， | 型に比較して ||- $\mathrm{a}$ 型で有意に低く， ||- $\mathrm{a}$ 型に比較して ||$-b$ 型で有意に低値を示した. 血圧低 下発生率は, I 型群で $4.7 \%, \quad I-\mathrm{a}$ 型群で 15.8\%, II-b 型で 40.7\%であった. HD 施行中の SDPTG 波形はさまざ まに変化し, 血圧低下発生と関連することが示唆された. HD 施行中のSDPTG 波形によって, 血圧低下発生を発見 できる可能性が考えられる.

\section{The relationship between intradialytic hypotension and the second-order derivative of plethysmogram}

Naoki Suzuki', Yuko Mizuno-Matsumoto ${ }^{2}$, Yuki Kawasaki ${ }^{1}$, Ginpei Tachibana ${ }^{1}$, Chiho Oshikawa', Yukiko Hasuike $^{3}$, Takeshi Nakanishi ${ }^{3}$

${ }^{1}$ The Hospital of Hyogo College of Medicine, Division of Clinical Engineering, ${ }^{2}$ Graduate School of Applied Informatics, University of Hyogo, ${ }^{3}$ Division of Kidney and Dialysis, Department of Internal Medicine, Hyogo College of Medicine

Key words : intradialytic hypotension, second-order derivative of plethysmogram, hemodialysis, blood volume, atherosclerosis

\section{$\langle$ Abstract〉}

【Background】 Intradialytic hypotension is associated with a risk of mortality in patients undergoing hemodialysis. The second-order derivative of plethysmogram (SDPTG) is a sensing tool that monitors cardiac functions such as cardiac output and peripheral vascular resistance. In the present study, the relationship between hypotension and the SDPTG waveform during dialysis was investigated.【Method】 Eighty-one patients undergoing hemodialysis were investigated in this study. Blood pressure (BP), SDPTG, and the changing rate of blood volume $(\triangle \mathrm{BV})$ were measured in pre-, intra-, and post-hemodialysis sessions. Hypotension was defined as a $>40$ $\mathrm{mmHg}$ decrease in systolic BP. The waveform of SDPTG consists of the a, b, c, and d waves in systole and the e wave in diastole. We categorized the waveform by the height of the waves : the $c$ wave was higher than the $d$ wave (type I), the $c$ wave was lower than the $d$ wave (type II-a), and the $c$ wave disappeared from the waveform (type II-b). Logistic regression analysis was used to assess the effect on hypotension of the SDPTG waveform during hemodialysis.【Result】 Hypotension occurred 33 times among the $360 \mathrm{BP}$ measurements in intrahemodialysis. The BPs of the type II-a and II-b groups were significantly lower than that of the type I group. The type II-b group showed significantly lower BP than the type II-a group. The occurrence rates of IDH were

鈴木 尚紀 兵庫医科大学病院臨床工学室％ 663-8501 兵庫県西宮市武庫川町 1-1

Naoki Suzuki Tel : 0798-45-5292 Fax : 0798-45-6952

〔受付日：2014 年 4 月 4 日, 受理日：2014 年 8 月 26 日〕 
4.7\% (reference), 15.8\% (odds ratio (OR) 3.03; $95 \%$ confidence interval (Cl) 1.1 to 7.9 ), and 40.7\% (OR 9.5; $95 \% \mathrm{Cl} 3.3$ to 27.1 ) in the type I , II-a, and II-b groups, respectively.【Conclusion】 The changes in waveform on SDPTG were associated with BP variations during a dialysis session. These results suggest that SDPTG is useful as an indicator of intradialytic hypotension.

\section{I . 緒言・目的}

血液透析（hemodialysis：HD）施行中の急激な低血 圧（透析時低血圧）は最も頻度が高い合併症のひとつ であり，HDの継続を困難にするだけでなく, HD 患者 の日常生活動作や生活の質を著しく低下させる. Shoji $ら^{1)}$ は, HD 施行中の収縮期血圧 $40 \mathrm{mmHg}$ 以上の低下 は 2 年間の死亡率に対するリスクの増加と関連すると 報告した。また，透析時低血圧はバスキュラーアクセ ス（VA）における血栓形成や脳梗塞にも関連し，さ まざまな合併症の原因となる2.3).

生体に扔ける血圧は，心拍出量と末梢血管抵抗のバ ランスによって維持される. 脈波 (plethysmogram： PTG）は心拍出量や血管状態によって恋化する波形で あり，HD施行中に打いて多様に変化する。また，PTG を二次微分して得られる二次微分脈波（second derivative of plethysmogram : SDPTG）は，その変曲点を 明膫にし，呼吸変動などによる基線の動摇の影響を排 除できることから，PTG を代用する簡易指標とされて いる).

PTG と SDPTG との関係を図 1 に示す.PTG は主 に収縮期前方成分と，後方成分とに分けられ，SDPTG において収縮期前方成分は $\mathrm{a}$ 波および $\mathrm{b}$ 波, 収縮期後 方成分は c 波抢よび d 波に相当する ${ }^{5)}$. SDPTGの各パ ラメー夕は末梢循環動態と関連し, c/a は一回心拍出 量と ${ }^{6)}, \mathrm{d} / \mathrm{a}$ は末梢血管抵抗との関連 ${ }^{7.8)}$ が報告されて いる。 また，佐野ら ${ }^{4)}$ は, SDPTG を代表的な 7 波形に 分類し，加齢変化に伴い波形が変化することを報告し た.

本研究に打いて測定された HD 患者の SDPTG は, 佐野らの波形分類に該当しない異常波形が一部に認め られた。そこでわれわれは，HD患者における SDPTG 波形を，従来報告されてきた正常型と，本研究におい て認められた異常型波形とに分類し，HD 施行前の SDPTG 波形パターンの違いによる患者因子の特徵 と, HD 施行中に反復測定したSDPTG 波形と血圧と の関連性について検討した.

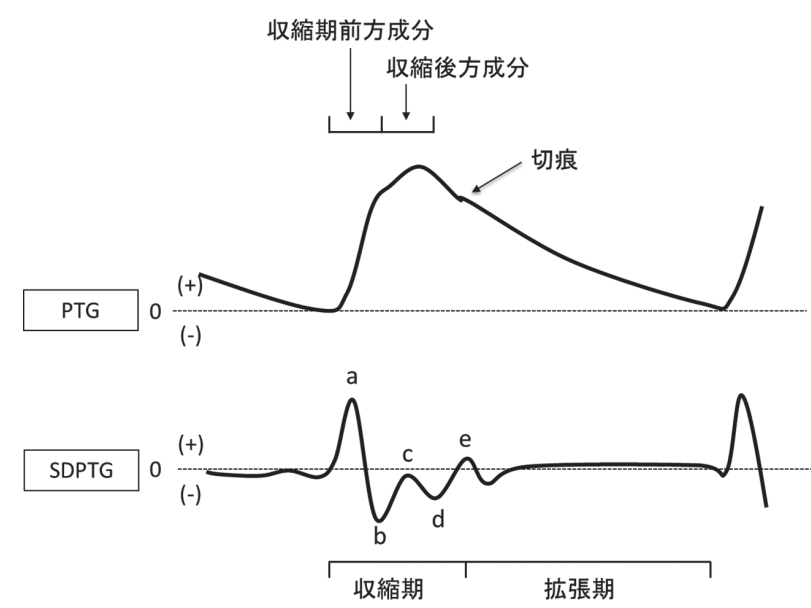

図 1 容積脈波と二次微分脈波との対応

PTG : 容積脈波, SDPTG : 二次微分脈波

\section{II. 対象と方法}

\section{1. 対 象}

対象は 2012 年 11 月から 2013 年 8 月の調査期間中に $\mathrm{HD}$ を施行した末期腎不全患者 81 名とした。なお，本 研究は, 兵庫医科大学倫理委員会の承認（第 1456 号） を得て扮り，事前に患者に対し十分な説明を行い，文 書による同意を得て施行された。

\section{2. 測定・調査項目}

患者因子として, 性別および年齢, ドライウェイト， 心駆出率, 透析期間, 心胸比, ヘマトクリット (Ht), $\mathrm{HD}$ 施行前血圧，脈拍を調査した，血管障害に関連す る合併症として, 糖尿病 (diabetes mellitus:DM) や 血管石灰化，末梢動脈疾患（peripheral arterial disease：PAD）の有無を調查した．血管石灰化の有無に ついては, 胸腹部 CT 画像または胸部 X 線画像より, 大動脈に石灰化が確認された患者を血管石灰化有りと した，透析条件として，血流量，透析時間，除水量を 調查した，循環動態の指標として血圧（収縮期，拡張 期, 平均) および循環血液量の変化率 $(\Delta \mathrm{BV})$ を測定 した。

\section{3. 測定方法}

測定間隔を図 2 に示す. HD 開始前，5 分後，60 分 後, 120 分後, 180 分後, 240 分後，回収後に，之れぞ れSDPTG および血圧を測定した．SDPTGはVA肢 反対側の第二指にプローブを装着し，100 拍における 


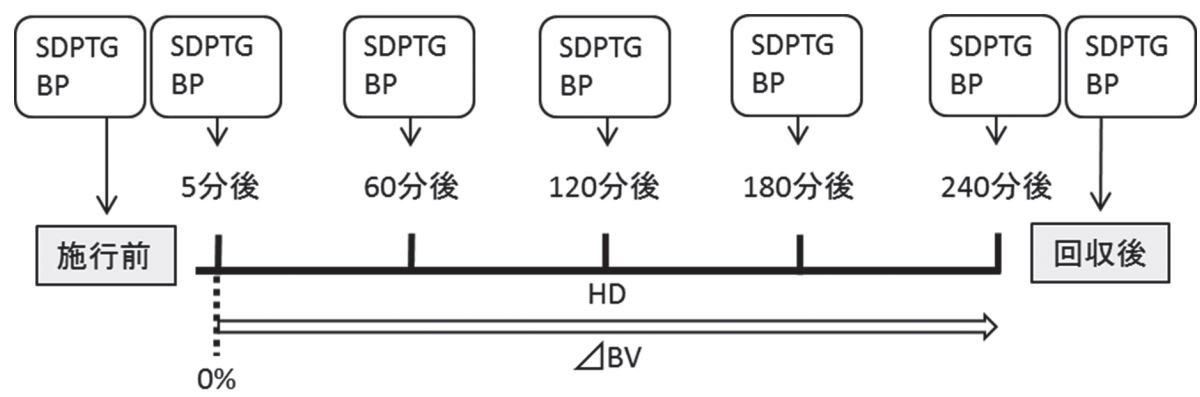

図 2 測定間隔

SDPTG : 二次微分脈波, $\mathrm{HD}$ : 血液透析, $\mathrm{BP}$ : 血圧, $\triangle \mathrm{BV}$ : 循環血液量の変化率

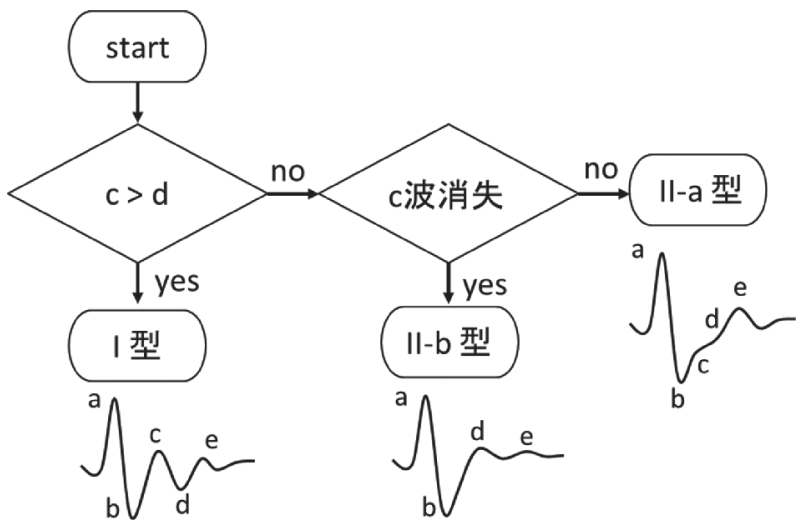

図 3 SDPTG 波形の分類方法

SDPTG：二次微分脈波

a 波, b 波, $\mathrm{c}$ 波, d 波, e 波の平均波高值をそれぞれ 算出した，血圧はVA 肢反対側の上腕で測定した. $\triangle \mathrm{BV}$ は HD 施行 5 分後を $0 \%$ として連続的に測定し, 血圧およびSDPTGの測定と同時に記録した. SDPTG の測定にはアルテット $\mathrm{CDN}^{\circledR}$ (U-Medica 社製), $\Delta \mathrm{BV}$ の測定にはクリットラインモニタ ${ }^{\circledR}$ (JMS 社製）を用 いた.

$\mathrm{HD}$ 施行中, $\mathrm{HD}$ 前に比較し, 一度でも $40 \mathrm{mmHg}$ 以 上の収縮期血圧の低下を認めた群を透析時低血圧群と した。一度も認められなかった群を透析時血圧不変群 とした. 透析時低血圧群の中で, HD 開始前, 5 分後, 60 分後, 120 分後, 180 分後, 240 分後, 回収後のそれ ぞれの時点において，HD 施行前よりも収縮期血圧が $40 \mathrm{mmHg}$ 以上低下した時点を血圧低下発生とした。

\section{SDPTG の波形分類}

本研究では新たにSDPTGの波形分類を作成した. SDPTGの波形分類方法を図 3 に示す。本研究では, c 波の波高值が d 波よりも高い波形を正常型（I 型）波 形，それ以外を異常型（II 型）とした。 II 型について は, c 波の波高值が $\mathrm{d}$ 波よりも低值である波形を II - $\mathrm{a}$ 型, c 波が消失した波形を II-b 型とした.

\section{5. 検討方法}

\section{1 ）患者背景因子の特徴}

透析時低血圧と患者背景因子との関連性を検討する ため, 透析時低血圧群と透析時血圧不変群とに群分け し，患者因子および合併症， HD 条件を比較した．統 計解析には Mann-Whitney U testまたは chi-squaretestを用いた。

また, HD 施行前の SDPTG 波形と患者背景因子と の関連性を検討するため, HD 施行前の SDPTG 波形 を I 型とII型に群分けし, 患者因子および合併症を比 較した。

2) HD 施行中における SDPTG 波形と血圧および $\triangle \mathrm{BV}$ との関連性

$\mathrm{HD}$ 施行中の血圧と SDPTG 波形の関連性を検討す るため, HD 開始 5 分後, 60 分後, 120 分後, 180 分 後, 240 分後の SDPTGの各パラメータ (b/a, c/a, $\mathrm{d} / \mathrm{a}, \mathrm{e} / \mathrm{a})$ と血圧および $\Delta \mathrm{BV}$ との関連を相関解析に よって検討した。

また, 各測定ポイントにおけるSDPTG 波形を I 型, II-a 型，II-b 型に群分けし，それぞれの波形を示し た際の血圧および $\Delta \mathrm{BV}$ について, Tukey-Kramer 法 およびBonferroni 法で補正した Wilcoxon single rank testを用いて群間比較を行った.

3 ） HD 施行中における血圧低下発生と SDPTG 波形 の関連性

$\mathrm{HD}$ 施行中の血圧低下発生と, 血圧低下発生時点に おける SDPTG 波形との関連性を検討するため, HD 開始 5 分後, 60 分後, 120 分後, 180 分後, 240 分後に おける血圧低下発生に対する各 SDPTG 波形のオッズ 比および $95 \%$ 信頼区間 $(95 \% \mathrm{CI})$ を多変量ロジス ティック回帰によって算出した. 多変量ロジスティッ ク回帰モデルにおける調整因子には, 時間とともに変 動し, HD施行中の血圧低下と関連する $\Delta \mathrm{BV}$ を選択し た. $\Delta \mathrm{BV}$ は $-10 \%$ 未満, $-10 \%$ 以上 $-5 \%$ 未満, $-5 \%$ 以上 $0 \%$ 未満, $0 \%$ 以上 $5 \%$ 未満にコード化した。 
表 1 透析時低血圧による患者背景因子の特徵

\begin{tabular}{|c|c|c|c|}
\hline & $\begin{array}{c}\text { 透析時低血圧群 } \\
(\mathrm{N}=13)\end{array}$ & $\begin{array}{c}\text { 透析時血圧不変群 } \\
(\mathrm{N}=68)\end{array}$ & $\mathrm{p}$ value \\
\hline \multicolumn{4}{|l|}{ 患者因子 } \\
\hline 年齢（歳） & $70.0(64.0-82.0)$ & $69.0(61.0-74.3)$ & n. s. \\
\hline 男性/女性 & $8 / 5$ & $50 / 18$ & n. s. \\
\hline ドライウェイト（kg） & $55.0(50.6-56.7)$ & $54.5(44.2-59.9)$ & n. $\mathrm{s}$. \\
\hline 心胸比（\%） & $54.5(53.5-57.5)$ & $53.0(49.0-58.0)$ & n. s. \\
\hline 透析歴（月） & $70.0(40.0-148.0)$ & $45.0(1.9-120.0)$ & n. s. \\
\hline 心駆出率（\%) & $66.0(53.0-83.0)$ & $65.0(56.3-70.0)$ & n. s. \\
\hline \multicolumn{4}{|l|}{$\mathrm{HD}$ 施行前血圧 $(\mathrm{mmHg})$} \\
\hline 収縮期 & $153.0(142.0-167.0)$ & $141.0(126.8-163.5)$ & n. s. \\
\hline 拡張期 & $70.3 \pm 12.1$ & $71.0(64.0-86.5)$ & n. $\mathrm{s}$. \\
\hline 平均 & $71.0(71.0-107.4)$ & $94.4 \quad(84.2-111.3)$ & n. s. \\
\hline 脈拍（bpm） & $79.0(78.0-89.0)$ & $75.0(65.3-88.0)$ & n. s. \\
\hline \multicolumn{4}{|l|}{ 合併症 } \\
\hline DM & $10(76.9 \%)$ & $25(26.8 \%)$ & $<0.05$ \\
\hline 血管石灰化 & $12(92.3 \%)$ & $42(61.8 \%)$ & $<0.05$ \\
\hline PAD & $3(21.0 \%)$ & $14(20.6 \%)$ & n. s. \\
\hline \multicolumn{4}{|l|}{ 透析条件 } \\
\hline 透析時間（時間） & $4.0(4.0-4.0)$ & $4.0(3.0-4.0)$ & n. s. \\
\hline 血液流量（mL/min） & $200(150-200)$ & $200(150-200)$ & n. s. \\
\hline 除水量（mL） & $1,960 \quad(1,600-2,300)$ & $1,700 \quad(1,200-2,200)$ & n. s. \\
\hline
\end{tabular}

表 $2 \mathrm{HD}$ 施行前における SDPTG 波形による患者因子の特徴

\begin{tabular}{|c|c|c|c|c|}
\hline & $\begin{array}{l}\text { 全患者 } \\
(\mathrm{N}=81)\end{array}$ & $\begin{array}{c}\text { I 型波形患者 } \\
\quad(\mathrm{N}=69)\end{array}$ & $\begin{array}{c}\text { II 型波形患者 } \\
\quad(\mathrm{N}=12)\end{array}$ & $\mathrm{p}$ value \\
\hline \multicolumn{5}{|l|}{ 患者因子 } \\
\hline 年齢（歳） & $69.0(60.0-76.0)$ & $69.0(60.0-77.0)$ & $69.5(61.0-73.0)$ & n. s. \\
\hline 男性/女性 & $48 / 33$ & $39 / 30$ & $9 / 3$ & n. s. \\
\hline ドライウェイト（kg） & $54.8(47.1-60.9)$ & $54.3(46.1-60.4)$ & $56.4(51.6-65.9)$ & n. s. \\
\hline 心胸比（\%） & $54.0(49.0-58.0)$ & $54.0(49.0-58.0)$ & $55.5(49.8-57.5)$ & n. s. \\
\hline 透析歴（月） & $28.0(3.0-88.5)$ & $25.0(1.4-82.0)$ & $44.0(12.0-148.0)$ & n. s. \\
\hline 心駆出率（\%) & $65.0(53.0-70.0)$ & $65.0(53.0-74.1)$ & $58.0(45.0-72.0)$ & n. s. \\
\hline \multicolumn{5}{|l|}{ HD 施行前血圧 (mmHg) } \\
\hline 収縮期 & $144.0(126.5-165.0)$ & $144.0(129.5-166.0)$ & $129.5(113.25-155.0)$ & n. s. \\
\hline 拡張期 & $72.0(65.0-86.0)$ & $74.0(66.0-86.0)$ & $68.0(54.8-101.3)$ & n. s. \\
\hline 平均 & $97.0(86.2-111.4)$ & $98.3(87.9-112.0)$ & $91.2(75.2-104.9)$ & n. s. \\
\hline 脈拍（bpm） & $80.0(70.0-89.0)$ & $80.0(70.0-88.5)$ & $83.0(67.8-91.3)$ & n. s. \\
\hline \multicolumn{5}{|l|}{ 合併症 } \\
\hline $\mathrm{DM}$ & $30(37.0 \%)$ & $24(34.8 \%)$ & $6(50.0 \%)$ & n. s. \\
\hline 血管石灰化 & $50(61.7 \%)$ & $38(55.1 \%)$ & $12(100.0 \%)$ & $<0.01$ \\
\hline PAD & $21 \quad(25.9 \%)$ & $15(21.7 \%)$ & $6(50 \%)$ & $<0.05$ \\
\hline
\end{tabular}

中央值（四分位範囲）

$\mathrm{HD}$ : 血液透析, DM : 糖尿病, PAD : 末梢動脈疾患, SDPTG : 二次微分脈波

\section{III. 結果}

\section{1. 患者背景因子の特徵}

透析時低血圧による患者背景因子の特徴を表 1 に示 す. 透析時低血圧群は対象患者 81 名中 13 名であった. 透析時低血圧群では透析時血圧不変群に比較して DM の合併率, 血管石灰化の合併率が有意に高值であった。

$\mathrm{HD}$ 施行前の SDPTG 波形による患者背景因子の比 較結果を表 2 に示す。HD 施行前の SDPTG は， I 型 群が 69 名，II 型群が 12 名であった，II 型群では，す べての患者に血管石灰化病変，50\%の患者に PAD が
認められ，それらの合併率は I 型群に比較して有意に 高かった。

\section{HD 施行中における SDPTG 波形と血圧および $\triangle \mathrm{BV}$ との関連性}

$\mathrm{HD}$ 施行中における SDPTG の b/a， c/a， d/a，e/a の平均值はそれぞれ， $-0.51 \pm 0.27,-0.10 \pm 0.16$, $-0.36 \pm 0.20,0.13 \pm 0.87$ であった. HD 施行中におけ る SDPTGの各パラメータと血圧および $\Delta \mathrm{BV}$ との相 関解析結果を表 3 に示す. HD 施行中の b/a および $\mathrm{c} /$ $\mathrm{a}$ は血圧との間に有意な正の相関が認められた。 $\mathrm{d} / \mathrm{a}$ および $\mathrm{e} / \mathrm{a}$ と血圧との間には負の相関が認められた が，相関係数は低值を示した. SDPTGの各パラメー 
表 $3 \mathrm{HD}$ 施行中における SDPTG のパラメータと血圧および $\Delta \mathrm{BV}$ との関連

\begin{tabular}{ccccccccccccccc}
\hline \multicolumn{2}{c}{ SDPTG } & \multicolumn{3}{c}{ 収縮期血圧 } & \multicolumn{3}{c}{ 拡張期血圧 } & \multicolumn{3}{c}{ 平均血圧 } & \multicolumn{3}{c}{$\Delta$ BV } \\
\hline パラメータ & $\mathrm{n}$ & $\mathrm{R}$ & $\mathrm{R}$ RSE & $\mathrm{p}$ value & $\mathrm{R}$ & $\mathrm{RMSE}$ & $\mathrm{p}$ value & $\mathrm{R}$ & RMSE & $\mathrm{p}$ value & $\mathrm{R}$ & RMSE & $\mathrm{p}$ value \\
\hline $\mathrm{b} / \mathrm{a}$ & 360 & 0.43 & 24.18 & $<0.01$ & 0.44 & 16.34 & $<0.01$ & 0.44 & 16.34 & $<0.01$ & 0.03 & 4.27 & $\mathrm{n} . \mathrm{s}$. \\
$\mathrm{c} / \mathrm{a}$ & 333 & 0.40 & 23.07 & $<0.01$ & 0.41 & 15.40 & $<0.01$ & 0.44 & 13.64 & $<0.01$ & -0.09 & 4.28 & n. s. \\
$\mathrm{d} / \mathrm{a}$ & 360 & -0.17 & 26.42 & $<0.01$ & -0.18 & 17.88 & $<0.01$ & -0.19 & 17.88 & $<0.01$ & -0.02 & 4.27 & n. s. \\
$\mathrm{e} / \mathrm{a}$ & 360 & -0.08 & 26.73 & n. s. & -0.09 & 18.12 & $<0.05$ & -0.09 & 18.11 & $<0.05$ & 0.05 & 4.28 & n. s. \\
\hline
\end{tabular}

$\mathrm{c} / \mathrm{a}$ は c 波が消失した II - b 型波形 $(\mathrm{n}=27)$ を欠測值とした.

HD : 血液透析, SDPTG : 二次微分脈波, $\mathrm{R}$ : 相関係数, RMSE : root-mean-square error ; 誤差標準偏差
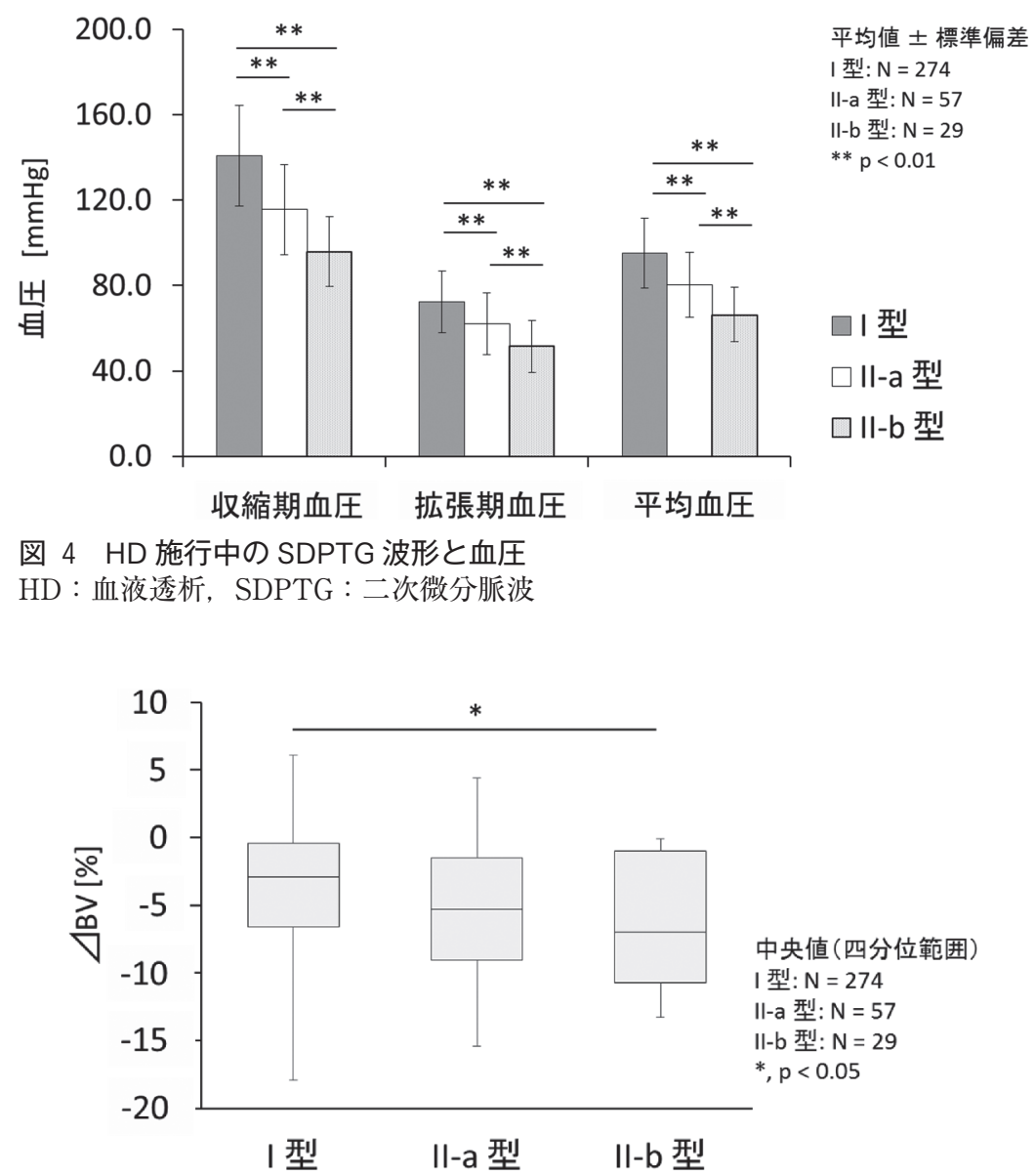

図 $5 \mathrm{HD}$ 施行中の SDPTG 波形と $\Delta \mathrm{BV}$

$\mathrm{HD}$ : 血液透析, SDPTG : 二次微分脈波, $\triangle \mathrm{BV}$ : 循環血液量の変化率

タと $\Delta \mathrm{BV}$ との間には相関関係は認められなかった。

I 型，II-a 型，II-b 型波形間における HD 施行中 の血圧を図 4 に示す. SDPTG および血圧の測定回数 は360 回であった。そのうち，I 型波形は $75.9 \%, I I-$ $\mathrm{a}$ 型波形は $15.9 \%$ ，II-b 型波形は $8.0 \%$ に認められた. $\mathrm{HD}$ 施行中， II- $\mathrm{a}$ 型と II - $\mathrm{b}$ 型波形を示した場合の血圧 は， I 型波形を示した場合の血圧に比較して有意に低 值であったささらに，II-b 型波形を示した場合の血圧 は，II-a 型波形を示した場合に比較して有意に低值で あった. I 型， II - $\mathrm{a}$ 型，II-b 型波形間の $\Delta \mathrm{BV}$ を図 5 に示す． II-b 型波形を示した場合の $\Delta \mathrm{BV}$ は I 型波形
を示した場合に比較して有意に低值であった。

\section{HD 施行中における血圧低下発生と SDPTG 波形 の関連性}

HD 開始 5 分後, 60 分後, 120 分後, 180 分後, 240 分後のそれぞれの時点における血圧低下発生回数は 33 回 $(9.2 \%)$ であった. HD 施行中の血圧低下発生に 対する SDPTG 波形の多変量ロジスティック回帰分析 結果を表 3 に示す. HD 施行中における血圧低下発生 率は， I 型波形で $4.7 \%(11 / 274$ 回)，II-a 型波形で 15.8\%（9/56 回），II-b 型波形で 40.7\%（13/27 回）で あった，血圧低下発生に対する調整済みオッズ比は, 
表 $4 \mathrm{HD}$ 施行中における血圧低下発生に対する SDPTG 波形のオッズ比

\begin{tabular}{lcccc}
\hline & OR $(95 \% \mathrm{CI})$ & $\mathrm{p}$ value & 調整済 OR $(95 \% \mathrm{CI})$ & $\mathrm{p}$ value \\
\hline SDPTG & & & & \\
I 型 & Reference & - & Reference & \\
II-a 型 & $4.1(1.6-10.2)$ & $<0.01$ & $3.03(1.1-7.9)$ & $<0.05$ \\
II-b 型 & $15.0(5.7-39.7)$ & $<0.01$ & $9.5(3.3-27.1)$ & $<0.01$ \\
$\Delta$ BV (5\%減少) & - & - & $3.02(1.9-5.1)$ & $<0.01$ \\
\hline
\end{tabular}

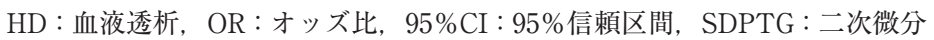

脈波, $\triangle \mathrm{BV}:$ 循環血液量の変化率

I 型波形を基準としたとき，II-a 型波形では 3.03 (95\%CI : 1.1-7.9)， II -b 型波形では $9.5 （ 95 \% \mathrm{CI}: 3.3-$ 27.1) であった。 また $\Delta \mathrm{BV}$ は $5 \%$ 減少するにしたがっ て，血圧低下に対する OR が $3.02(95 \% \mathrm{CI}: 1.9-5.1)$ 増 加する結果となった。

\section{IV. 考察}

\section{HD 患者における SDPTG 波形の特徵}

HD 施行前の SDPTG が II 型波形を示す患者では, I 型波形患者に比較して血管石灰化や PAD の合併率 が高く, SDPTG 波形と動脈硬化疾患とが関連するこ とが示唆された。佐野ら ${ }^{4)}$ は，健常者から中高年者を 対象とした検討によって SDPTG 波形を 7 波形に分類 した.そのすべての波形において $\mathrm{c}$ 波高值が $\mathrm{d}$ 波高值 よりも高い結果であったが，本研究では $\mathrm{c}$ 波高值が $\mathrm{d}$ 波高值よりも低いか, c 波が消失した異常型の II 型波 形が認められた．SDPTGにおける c 波, d 波は, PTG において末梢血管による反射波成分である収縮期後期 隆起に相当する。動脈硬化の進行した患者では末梢血 管の収縮・拡張機能が障害されているため ${ }^{9)}$, PTGに おける収縮後期隆起が不明瞭になり, SDPTGにおけ るII 型波形を示したと考えられた.

\section{HD 施行中における SDPTG 波形と血圧との関連 性}

$\mathrm{HD}$ 施行中，血圧は， I 型波形に比較して II - $\mathrm{a}$ 型波 形を示した場合に低值を示し，II-a 型波形に比較して II - b 型波形を示した場合に低值を示した。また SDPTGにおける $\mathrm{c} / \mathrm{a}$ と血圧との間に有意な正の相関, $\mathrm{d} / \mathrm{a}$ と血圧の有意な負の相関が認められた. 先行研究 では SDPTGにおける c 波と一回心拍出量との間に正 の相関関係があることや ${ }^{6)}$, 血管拡張薬投与によって $\mathrm{d} / \mathrm{a}$ が上昇, アンジオテンシンの投与によって $\mathrm{d} / \mathrm{a}$ が 低下することが報告されている ${ }^{10,11)}$ 。また, SDPTGの $\mathrm{c}$ 波成分である PTG の収縮後期隆起は, 低心拍出量状 態で小さくなり，ときに消失することが報告されてい る ${ }^{12)}$. これらから, SDPTG 波形は心拍出量や血管の 機能的緊張の変化を表現するため, SDPTG 波形と血
圧との関連が認められたと考えられる。

$\mathrm{HD}$ 施行中の血圧低下発生に対しては, SDPTG 波形 の調整済み OR が I 型波形に比較して II - $\mathrm{a}$ 型波形, II -b 型波形で有意に高值であった。この結果より， SDPTG 波形と HD 施行中の血圧低下発生との間には, $\triangle \mathrm{BV}$ とは独立した関連性があることが示唆された。 また II-b 型波形を示した際の $\Delta \mathrm{BV}$ は I 型波形に比較 して有意に低值を示したことからも，HD 施行中の II $\mathrm{a}$ 型（c 波低下)， II - b 型波形（c 波消失）は，一回心 拍出量と末梢血管抵抗のバランスが崩れた状態を示し ていたと推測される. 特に, II-b 型波形は一回心拍出 量の低下が著しい状態であったと考えられる.

\section{SDPTG 測定における臨床的意義と可能性}

透析時低血圧の原因として，DM 患者に認められる 自律神経障害や動脈硬化の進展による血管反応性の低 下 $^{13)}, \Delta \mathrm{BV}$ の低下や心機能低下による心拍出量の減 少が考えられている ${ }^{8)}$. 本研究においても, 透析時低 血圧群では，DM 患者や血管石灰化患者の割合が高い ことや， $\triangle \mathrm{BV}$ が5\%低下するに従い血圧低下発生に対 する OR が上昇することが示唆された。これらの結果 からも，血管反応性と心拍出量とが透析時低血圧と関 連していることがわかる，従って，HD 施行中の血圧 変動を予測するためには，これらの指標を同時にモ二 タリングする必要がある. SDPTGは心拍出量や末梢 血管反応，血管壁の器質的硬化の影響を受け変化する 波形であることから，血圧変動の指標として応用でき る可能性がある。 また, SDPTG は非侵襲的かつ連続 的に測定することが可能であり，SDPTGをリアル夕 イムに解析することができれば，HD 施行中の I 型波 形から II - $\mathrm{a}$ 型波形への変化や II - b 型波形への変化と いった現象をイベントとして捉えることで，その時点 における血圧低下発生を発見できる可能性が考えられ る。

\section{4. 本研究の限界}

本研究における血圧低下発生に対する SDPTG 波形 の多変量ロジスティック回帰では，過剩適合の可能性 を除外するために，調整因子を $\Delta \mathrm{BV}$ のみとた， $\mathrm{HD}$ 中の血圧低下に関連する因子としては，ほかにも DM 
や血管石灰化の有無，除水量が考えられる．除水量に 関しては, $\triangle \mathrm{BV}$ との負の線形相関が認められたため, 多重共線性ありとして調整因子から除外した。除水量 は一般的に透析時の血圧と関連することが知られてい るが, 本研究では透析時低血圧群と透析時血圧不変群 とでは有意な差は認められなかった。

また，本研究ではSDPTG と血圧とを同時に測定し たため，血圧低下の前にSDPTG が変化するのか，血 圧低下が発生したために SDPTG 波形が変化している のかということを明らかにすることができなかった. 今後さらなる検討を行い, SDPTG 波形変化による血 圧低下の予測指標としての妥当性を明らかにする必要 がある。

\section{結 論}

HD 施行前の SDPTG が II 型波形を示した患者では, 血管石灰化やPAD の合併率が高いことが示唆された. また HD 施行中の SDPTG 波形はさまざまに変化し， 血圧低下発生と関連することが示唆された，HD 施行 中の SDPTG 波形によって, 血圧低下発生を発見でき る可能性が考えられる.

\section{文献}

1) Shoji T, Tsubakihara Y, Fujii M, Imai E. Hemodialysis-associated hypotension as an independent risk factor for two-year mortality in hemodialysis patients. Kidney Int 2004; 66: 1212-20.

2) Chang TI, Paik J, Greene T, et al. Intradialytic hypotension and vascular access thrombosis. J Am Soc Nephrol 2011; 22: 1526-33.

3) Ishida I, Hirakata H, Sugimori H, et al. Hemodialysis causes severe orthostatic reduction in cerebral blood flow velocity in diabetic patients. Am J Kidney Dis 1999; 34: 1096-104.

4）佐野祐司，片岡幸雄，生山匡，他. 加速度脈波による 血液循環の評価とその応用. 労働科学 $1985 ； 61 ： 129-$ 43.

5）池谷俊朗, 高沢謙二, 山科晃. 高血圧による動脈硬化 度を評価する指尖容積脈波（加速度脈波）。血圧 2003； 10: $1347-86$.

6）鈴木明祐, 山川和樹, 藤沼秀光, 須藤秀明, 小川研一. 弾性動脈の伸展度（Distensibility）と，加速度脈波と の関係についての検討（完全房室ブロック患者の VVI ペーシング時の特徵的循環動態を用いて. 日臨生理会 誌 1990；20：113-23.

7）高沢謙二, 伊吹山千晴. 加速度脈波の有用性. 臨検 1989；33: 858-62.

8）山本壱弥, 小林直之, 松永篤彦, 他. 維持血液透析時 に認められる過剩な血圧低下の出現機序に関する検 討. 透析会誌 2007；40：894-906.

9）高沢謙二. 大動脈硬化と末梢循環について一Augmentation Index (AI) 一. Cardiac Practice 1996; 7: 216.

10) Takazawa K, Tanaka N, Fujita M, et al. Assessment of vasoactive agents and vascular aging by the second derivative of photoplethysmogram waveform. Hypertension 1998; 32: 365-70.

11）熟野嘉映，高田晴子，岩田弘敏. 加速度脈波波形に及 ぼすニトログリセリン負荷, 寒冷負荷, 及び起立負荷 の影響. 日臨生理会誌 1996；26：145-53.

12）増田善昭, 金井寛. 脈波波形. 動脈脈波の基礎と臨床. 東京：共立出版, 2000；9-14.

13) Hirakata $H$, Nitta $K$, Inaba $M$, et al. Japanese Society for Dialysis Therapy. Japanese Society for Dialysis Therapy guidelines for management of cardiovascular diseases in patients on chronic hemodialysis. Ther Apher Dial 2012; 16: 387-435. 